\title{
A testicular and paratesticular localization of Desmoplastic Small Round Cell Tumor: Is it a good prognostic factor?
}

\author{
Fabricio Romagnol ${ }^{1}$, Maria Teresa Alves ${ }^{1}$, Marília Oliveira $^{1}$, Eny Carvalho ${ }^{2}$, Ana Maria da \\ Silva $^{2}$, and Eliana Caran ${ }^{1}$ \\ ${ }^{1}$ Federal University of Sao Paulo \\ ${ }^{2}$ Hospital Martagao Gesteira
}

October 12,2020

\begin{abstract}
Desmoplastic Small Round Cell Tumor (DSRCT) is an aggressive neoplasm that classically grows in peritoneal cavity and has poor prognosis. We describe a 13-year old boy with testicular DSRCT, treated with orchiectomy and chemotherapy and is free of disease 96 months after diagnosis. This is the fifth case of primary DSRCT of the testis described in literature. Moreover, we present a literature review of 28 cases of testicular and paratesticular DSRCT and discuss these locations as a prognostic factor.
\end{abstract}

\section{Introduction}

Desmoplastic Small Round Cell Tumor (DSRCT) is a rare neoplasm that affects mainly adolescent and young adult males. This tumor presents with a polyphenotypic differentiation profile, showing muscular, neural and epithelial markers and carries the recurrent chromosomal translocation $\mathrm{t}(11 ; 22)(\mathrm{p} 13 ; \mathrm{q} 12)^{\mathbf{1 , 2}}$. Abdomen/pelvis are the major sites of growth and the prognosis is poor, but data from literature shows that patients with paratesticular DSRCT have better outcomes ${ }^{2-4}$. We present the fifth case of primary DSRCT of the testis described in literature and discuss these locations as a prognostic factor.

\section{Case Description}

A 13-year-old boy presented with a 9-month history of right testicle swelling. Ultrasound and magnetic resonance imaging of the scrotum revealed a $1.7 \times 1.4 \mathrm{~cm}$ solid nodule in the right testis (Figure 1) and he underwent a right radical orchiectomy. Histopathological exam showed a whitish neoplastic proliferation in testicular tissue, measuring $1.9 \times 1.8 \mathrm{~cm}$, with trabecular arrangements interspersed with fibrous tissue and covered by small, round and blue cells, with few enlarged nuclei and scarce cytoplasm. The nodular tumor was confined to the testis and evaluation of spermatic cord was normal. Immunohistochemistry revealed diffuse positivity for cytokeratin AE1/AE3, neuron-specific enolase and desmin in dot-like pattern. There was also focal positivity for EMA. Chromogranin, synaptophysin, myogenin, inhibin and muscle-actin-specific HHF-35 were negative; INI-1 was intact. Ki-67 proliferation index was 20\%. Morphological and immunohistochemical findings were compatible with DSRCT. After diagnosis, the patient was referred for our hospital. Complementary staging exams did not show distant metastases. Next-Generation Sequencing by Illumina NextSeq 500 System was performed, and EWS-WT1 fusion gene was positive, confirming the diagnosis of DSRCT. We then started adjuvant chemotherapy, consisting of 10 cycles of Irinotecan $\left(50 \mathrm{mg} / \mathrm{m}^{2} / \mathrm{d}\right.$, day 1 to 5) and Vincristine $\left(1.5 \mathrm{mg} / \mathrm{m}^{2} / \mathrm{d}\right.$, day 1 and day 7$)$. No radiation therapy was performed. Currently the patient is disease-free 96 months after diagnosis.

\section{Discussion}


DSRCT is an aggressive tumor that develops in serous cavities, mainly in the abdomen/pelvis, and spreads generating multiple peritoneal implants. The age-adjusted incidence rate of DSRCT is 0,3 cases/million, with a peak incidence of 0,74 cases/million in those aged $20-24$ years $^{5}$. In a series of 60 patients, $93 \%$ had intraabdominal tumor and $90 \%$ had metastases at diagnosis ${ }^{6}$. Extra-abdominal DSRCT is rare, affecting about $5-27 \%$ of cases and was reported in several sites, like parotid glands, pleura, tibia and the paratesticular region $^{4,7-9}$.

Although paratesticular DSRCT has been reported since 1992, primary DSRCT of the testis was first described by He and colleagues in $2013^{\mathbf{1 0}}$. In our literature review we found 23 cases of paratesticular and 5 of testicular tumors, including the case here reported (Table 1). Of the 5 testicular DSRCT, 2 cases presented with extension to the epididymis/spermatic cord and in another case the tumor invaded rete testis with infiltration to lymphovascular spaces ${ }^{\mathbf{1 0 - 1 2}}$. Of the paratesticular tumors, not one infiltrated the testis. In contrast, testicular DSRCT seems to invade paratesticular regions. The present case report is the fifth testicular DSRCT in the literature.

Translocation $\mathrm{t}(11 ; 22)(\mathrm{p} 13 ; \mathrm{q} 12)$ is the hallmark of DSRCT and the fusion occurs in exon 7 of EWS gene and exon 8 of WT1 gene $\mathbf{2}^{\mathbf{1 3}, \mathbf{1 4}}$. This fusion results in a chimeric protein capable of acting as a transcription factor in more than 30 genes, such as the growth factor genes PDGF, EGFR and IGF-1 ${ }^{\mathbf{1 5}, 16}$. Although the EWS-WT1 transcript is characteristic of DSRCT, it is still not known if the fusion is specific to this disease. Alaggio et al described 2 cases of intra-abdominal leiomyosarcomas positive for the EWS-WT1 fusion in children 9 and 11 years old. One of the cases presented as a single abdominal mass and both had a favorable course $^{\mathbf{1 7}}$. Two cases that we reviewed presented unusual fusion with EWS in exon 9 and WT1 in exon 8, one a paratesticular DSRCT and the other testicular ${ }^{\mathbf{1 2 , 1 4}}$. Al-Ibraheemi described a series of 16 cases with DSCRT with atypical location; all of them presented the typical EWS-WT1 fusion, demonstrating that the molecular signature of DSRCT in atypical sites seems to be the same as of those in the abdomen, despite better outcomes ${ }^{\mathbf{1 8}}$.

Patients with abdominal DSRCT are usually diagnosed with advanced disease and have poor prognosis, with overall survival ranging from 12 to $33 \%$ in 5 years, even with multimodal treatment. Resectable and non-metastatic tumors have better outcomes, regardless of their location ${ }^{\mathbf{5 , 6 , 1 9 , 2 0}}$. Therefore, resectability is considered an independent prognostic factor. In a study by Wong et al, patients with non-metastatic, intra-abdominal disease at presentation who had undergone surgical resection of the primary tumor $(\mathrm{n}=6)$ survived much longer than those who did not have surgery $(n=11)$, with median survival of 47 versus 16 months, respectively $(\mathrm{p}=0.0235)^{\mathbf{2 1}}$.

Some studies suggest that patients with extra-abdominal tumors have better outcomes compared to the typical abdominal tumors ${ }^{3,21}$. Our review included 28 patients with testicular and paratesticular DSRCT. 6 of these were lost to follow-up. 12 out the remaining $22(54 \%)$ were disease-free between 6 and 120 months after diagnosis. Differences of survival between testicular and paratesticular DSRCT was not significant due to the small number of cases and variable follow-up.

Survival improves considerably in non-metastatic testicular/paratesticular DSRCT. Of the 12 available patients, 9 were disease-free between 6-120 months after diagnosis and 3 died, resulting in a $75 \%$ disease-free survival.

In DSRCT with metastasis at diagnosis, regardless of testicular or para-testicular location, only 2 out of 8 cases were alive without evidence of disease 6 and 30 months after diagnosis. In our review, the most frequent sites of metastasis at the time of initial diagnosis or at the time of recurrence diagnosis were retroperitoneal lymph nodes (9 cases) and lungs (6 cases).

Resection surgery was possible in $93 \%$ of patients with paratesticular/testicular DSRCT, with orchiectomy reported in 23 of 28 cases, signaling the high resectability of these tumors when compared to abdominal DSRCT, in which less than $50 \%$ are completely resected $^{\mathbf{6}, 20}$.

Currently, the most used chemotherapy regimen is based on alkylating agents, anthracyclines and vinca 
alkaloids. However, several different regimens are reported in the literature ${ }^{\mathbf{6}, 21}$. Our patient was treated with Irinotecan. Some authors have shown that topoisomerase inhibitors, such as Irinotecan, can be effective in $\mathrm{DSRCT}^{22-24}$.

There is no consensus in the literature regarding the treatment of patients with DSRCT in the paratesticular or testicular regions due to the small number of cases. In non-metastatic cases the initial treatment is

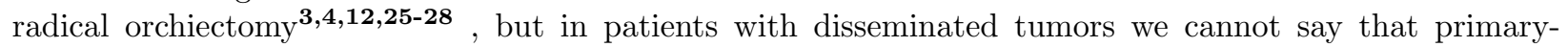
tumor-surgery improves survival. The administration of chemotherapy seems to be consensual due to the potentially aggressive behavior of the tumor. However, at least in paratesticular or testicular disease, it appears that radiotherapy can be avoided in tumors that are completely resected, although further studies are needed for definitive conclusions. In metastatic tumors multimodal treatment is mandatory, and the prognosis is poor regardless of the primary tumor location.

Efforts are being made to discover targeted therapies in DSRCT, however there is currently no drug that has a target effect in the EWS-WT1 fusion. Several agents, especially tyrosine kinase inhibitors, such as pazopanib, imatinib and sorafenib are being studied ${ }^{\mathbf{1 6}}$. A wide analysis of the genomic profile of DSRCT may provide data on whether other genetic alterations contribute to the growth and behavior of this tumor in different regions.

\section{Ethical statement}

Institutional Review Board approval was granted by the Federal University of Sao Paulo Research Ethics Committee, (reference no. 4.332.189) and the patient gave written informed consent for his de-identified clinical data to be published.

\section{Conflict of interest statement}

The authors declare that there is no conflict of interest. This research received no specific grant from any funding agency, commercial or not-for-profit sectors.

\section{Acknowledgements}

The authors would like to acknowledge the help of Thiago Moulin Ribeiro de Assis for assistance in language review.

\section{References:}

1. Gerald WL, Miller HK, Battifora H, Miettinen M, Silva EG, Rosai J. Intra-abdominal desmoplastic small round-cell tumor. Report of 19 cases of a distinctive type of high-grade polyphenotypic malignancy affecting young individuals. Am J Surg Pathol 1991, 15:499-513.

2. Ladanyi M \& Gerald W. Fusion of the EWS and WT1 Genes in the Desmoplastic Small Round Cell Tumor. Cancer Res 1994;54:2837-2840.

3. Saab R, Khoury JD, Krasin M, Davidoff AM, Navid F. Desmoplastic small round cell tumor in childhood: the St. Jude Children's Research Hospital experience. Pediatr Blood Cancer. 2007 Sep;49(3):2749.

4. Sedig L, Geiger J, Mody R, Jasty-Rao R. Paratesticular desmoplastic small round cell tumors: A case report and review of the literature. Pediatr Blood Cancer. 2017 Dec;64(12). doi: 10.1002/pbc.26631.

5. Lettieri CK, Garcia-Filion P, Hingorani P. Incidence and outcomes of desmoplastic small round cell tumor: results from the surveillance, epidemiology, and end results database. J Cancer Epidemiol. 2014;2014:680126. doi: 10.1155/2014/680126.

6. Scheer M, Vokuhl C, Blank B, et al. Desmoplastic small round cell tumors: Multimodality treatment and new risk factors. Cancer Med. 2019;8(2):527-542. doi:10.1002/cam4.1940.

7. Hatanaka KC, Takakuwa E, Hatanaka Y, et al. Desmoplastic small round cell tumor of the parotid gland-report of a rare case and a review of the literature. Diagn Pathol. 2019;14(1):43. Published 2019 May 18. doi:10.1186/s13000-019-0825-1. 
8. Cao Y, Chen Y, Yang LI, et al. Desmoplastic small round cell tumor: A case report of a rare differential diagnosis of solid tumors of the pleura. Oncol Lett. 2015;10(5):2991-2995. doi:10.3892/ol.2015.3680.

9. Xuesong D, Hong G, Weiguo Z. Primary desmoplastic small round cell tumor of the tibia: PET/CT and MRI presentation of a rare case and review of the literature. J Bone Oncol. 2019;20:100272. Published 2019 Dec 3. doi:10.1016/j.jbo.2019.100272.

10. He L, Wen S, Hu X, Guo C, Yi C. Primary desmoplastic small round cell tumor of the testis: A case report and review of the literature. Oncol Lett. 2013;6(2):565-567. doi:10.3892/ol.2013.1421.

11. Zhang GM, Zhu Y, Gan HL, Ye DW. Testicular desmoplastic small round cell tumor: a case report and review of literature. World J Surg Oncol. 2014;12:227. Published 2014 Jul 18. doi:10.1186/14777819-12-227.

12. Herman M, Chetty R, Dickson BC, Evans AJ, Razak A, Lewin J. Desmoplastic Small Round Cell Tumor Presenting as an Isolated Testicular Mass in an Adult With Multiple Previous Malignancies. Clin Genitourin Cancer. 2016;14(2):e221-e223. doi:10.1016/j.clgc.2015.12.026.

13. Mora J, Modak S, Cheung NK, Meyers P, de Alava E, Kushner B, Magnan H, Tirado OM, Laquaglia M, Ladanyi M, Rosai J. Desmoplastic small round cell tumor 20 years after its discovery. Future Oncol. 2015;11(7):1071-81. doi: 10.2217/fon.15.32.

14. Cliteur VP, Szuhai K, Baelde HJ, van Dam J, Gelderblom H, Hogendoorn PC. Paratesticular desmoplastic small round cell tumour: an unusual tumour with an unusual fusion; cytogenetic and molecular genetic analysis combining RT-PCR and COBRA-FISH. Clin Sarcoma Res. 2012;2(1):3. Published 2012 Jan 25. doi:10.1186/2045-3329-2-3.

15. Bulbul A, Fahy BN, Xiu J, et al. Desmoplastic Small Round Blue Cell Tumor: A Review of Treatment and Potential Therapeutic Genomic Alterations. Sarcoma. 2017;2017:1278268. doi:10.1155/2017/1278268

16. Bexelius TS, Wasti A, Chisholm JC. Mini-Review on Targeted Treatment of Desmoplastic Small Round Cell Tumor. Front Oncol. 2020 Apr 21;10:518. doi: 10.3389/fonc.2020.00518.

17. Alaggio R, Rosolen A, Sartori F, et al. Spindle cell tumor with EWS-WT1 transcript and a favorable clinical course: a variant of DSCT, a variant of leiomyosarcoma, or a new entity? Report of 2 pediatric cases. Am J Surg Pathol. 2007;31(3):454-459. doi:10.1097/01.pas.0000213375.02171.43.

18. Al-Ibraheemi A, Broehm C, Tanas MR, Horvai AE, Rubin BP, Cheah AL, Thway K, Fisher C, Bahrami A, Folpe AL, Fritchie KJ. Desmoplastic Small Round Cell Tumors With Atypical Presentations: A Report of 34 Cases. Int J Surg Pathol. 2019 May;27(3):236-243. doi: 10.1177/1066896918817140.

19. Hayes-Jordan A, LaQuaglia MP, Modak S. Management of desmoplastic small round cell tumor. Semin Pediatr Surg. 2016;25(5):299-304. doi:10.1053/j.sempedsurg.2016.09.005.

20. Honoré C, Delhorme JB, Nassif E, et al. Can we cure patients with abdominal Desmoplastic Small Round Cell Tumor? Results of a retrospective multicentric study on 100 patients. Surg Oncol. 2019;29:107-112. doi:10.1016/j.suronc.2019.04.002.

21. Wong HH, Hatcher HM, Benson C, et al. Desmoplastic small round cell tumour: characteristics and prognostic factors of 41 patients and review of the literature. Clin Sarcoma Res. 2013;3(1):14. Published 2013 Nov 26. doi:10.1186/2045-3329-3-14.

22. Rosoff PM, Bayliff S. Successful clinical response to irinotecan in desmoplastic round blue cell tumor. Med Pediatr Oncol. 1999;33:500-3. doi:10.1002/(sici)1096-911x(199911)33:5<500::aid-mpo12>3.0.co;2$\mathrm{x}$.

23. Hayes-Jordan A, Anderson P, Curley S, et al. Continuous hyperthermic peritoneal perfusion for desmoplastic small round cell tumor. J Pediatr Surg. 2007;42(8):E29-E32. doi:10.1016/j.jpedsurg.2007.05.047.

24. Ambar NBD, de Seixas Alves MT, Lederman HM, Abib S, Duarte AAB, Caran EM. Irinotecan and vincristine for the treatment of refractory desmoplastic small round cell tumor in a developing country: a case report. J Med Case Rep. 2019;13(1):77. Published 2019 Mar 10. doi:10.1186/s13256-019-1985-z.

25. Bertoldin R, Drei N, D'Incà G, Camuffo MC, Guazzieri S. A Paratesticular Localization of Desmoplastic Small Cell Tumor. A Case Report. Tumori Journal. 1996;82(5):497-498. https://doi.org/10.1177/030089169608200519.

26. Roganovich J, Bisogno G, Cecchetto G, D'Amore ES, Carli M. Paratesticular desmoplastic small 
round cell tumor: Case report and review of the literature. J SurgOncol. 1999;71(4):269-272. doi:10.1002/(SICI)1096-9098(199908)71:4<269::AID-JSO13>3.0.CO;2-M.

27. Bisogno G, Roganovich J, Sotti G, et al. Desmoplastic small round cell tumour in children and adolescents. Med Pediatr Oncol. 2000;34(5):338-342. doi:10.1002/(sici)1096-911x(200005)34:5<338::aidmpo4>3.0.co;2-0.

28. Prat J, Matias-Guiu X, Algaba F. Desmoplastic small round-cell tumor. Am J Surg Pathol. 1992;16(3):306-307.

29. Ordóñez NG, el-Naggar AK, Ro JY, Silva EG, Mackay B. Intra-abdominal desmoplastic small cell tumor: a light microscopic, immunocytochemical, ultrastructural, and flow cytometric study. Human Pathology. 1993 Aug;24(8):850-865. DOI: 10.1016/0046-8177(93)90135-4.

30. Farhat F, Culine S, Lhommé C, et al. Desmoplastic small round cell tumors: results of a four-drug chemotherapy regimen in five adult patients. Cancer. 1996;77(7):1363-1366. doi:10.1002/(SICI)10970142(19960401)77:7<1363::AID-CNCR21>3.0.CO;2-Z.

31. Cummings OW, Ulbright TM, Young RH, Dei Tos AP, Fletcher CD, Hull MT. Desmoplastic small round cell tumors of the paratesticular region. A report of six cases. Am J Surg Pathol. 1997;21(2):219225. doi:10.1097/00000478-199702000-00013.

32. Furman J, Murphy WM, Wajsman Z, Berry AD, 3rd. Urogenital involvement by desmoplastic small round-cell tumor. J Urol. 1997;158(4):1506-1509. https://doi.org/10.1016/S0022-5347(01)64254-X.

33. Kawano N, Inayama Y, Nagashima Y, et al. Desmoplastic small round-cell tumor of the paratesticular region: report of an adult case with demonstration of EWS and WT1 gene fusion using paraffinembedded tissue. Mod Pathol. 1999;12(7):729-734 (only abstract).

34. García-González J, Villanueva C, Fernández-Aceñero MJ, Paniagua P. Paratesticular desmoplastic small round cell tumor: case report. Urologic Oncology. 2005 Mar-Apr;23(2):132-134. DOI: 10.1016/j.urolonc.2004.09.009.

35. Thuret R, Renaudin K, Leclere J, et al. Uncommon malignancies: case 3. Paratesticular desmoplastic small round-cell tumor. Journal of Clinical Oncology : Official Journal of the American Society of Clinical Oncology. 2005 Sep;23(25):6253-6255. DOI: 10.1200/jco.2005.07.006.

36. Sha JJ, Lu JW, Zhu JS, Huang XY,Wang YX. Desmoplastic small roundcell tumor of the paratesticular region: A case report and review of the literature. Zhonghua Nan Ke Xue. 2007;13(10):918-920 (only abstract).

37. Rais H, Elmansouri F, Belaabidia B, EssadkiO, Oussehal A, Sarf I. Paratesticular desmoplastic small round cell tumour: Case report with literature review. Cancer Radiother. 2010;14(2):111-114.

38. Yue X, Wang JZ, Tian Y, Wang KJ. Paratesticular desmoplastic small round cell tumor with metastasis: a report of two cases. Kaohsiung J Med Sci. 2014;30(2):104-105. doi:10.1016/j.kjms.2013.01.018.

39. Manjula MV, Pawar YS. Primary desmoplastic small round cell tumor of the testis: First case in India and review of the literature. J Cancer Res Ther. 2015;11(3):650. doi:10.4103/0973-1482.138210.

Figure legend: Preoperative magnetic resonance showing coronal and sagittal T2 SPAIR images of a primary testicular mass measuring $1.7 \times 1.4 \mathrm{~cm}$ (arrow). 

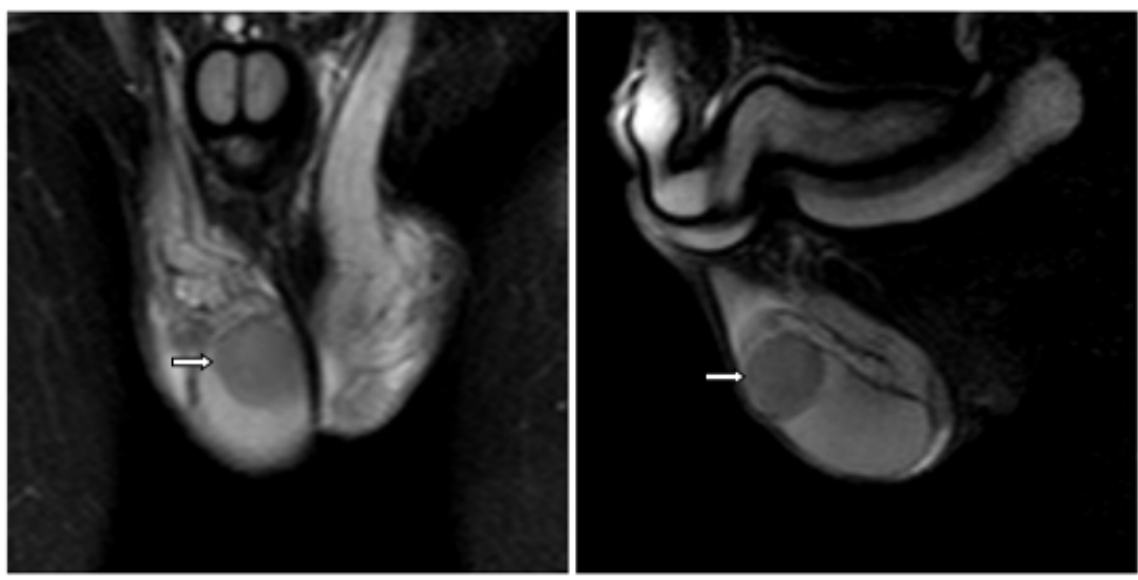

Hosted file

Table 1.pdf available at https://authorea.com/users/366445/articles/486209-a-testicularand-paratesticular-localization-of-desmoplastic-small-round-cell-tumor-is-it-a-goodprognostic-factor 